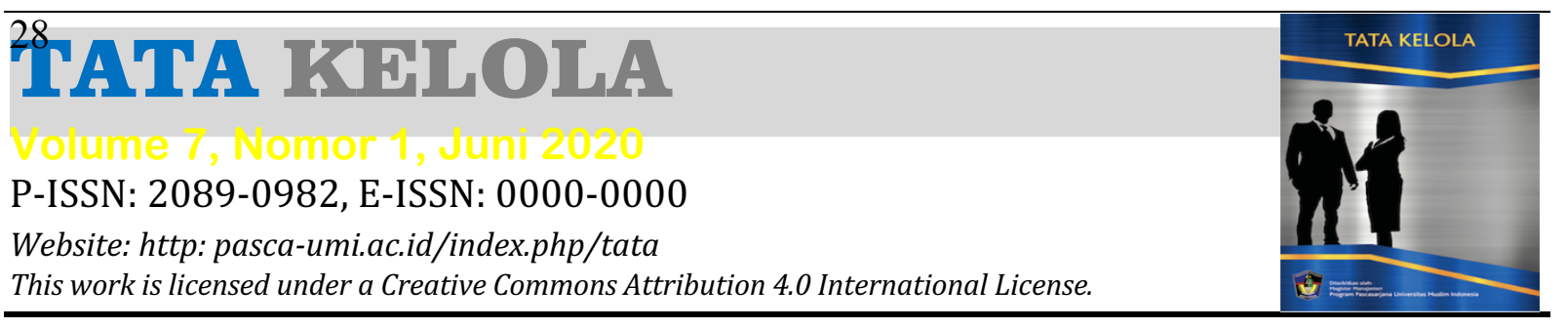

\title{
Pengaruh Faktor Lingkungan Kerja, Kompensasi dan Kemampuan Kerja Terhadap Kinerja Pegawai Pada Kelurahan Baju Bodoa Kecamatan Maros Baru Kabupaten Maros
}

\author{
Rudi, Abdul Rahman Mus ${ }^{2}$, Serlin Serang ${ }^{3}$ \\ 12,3, Magister Manajemen, Universitas Muslim Indonesia. \\ ${ }^{1}$ Koresponden Penulis, E-mail: purnaprajamaros@yahoo.co.id
}

\begin{abstract}
ABSTRAK
Penelitian ini bertujuan untuk mengetahui pengaruh faktor Lingkungan Kerja, Kompensasi dan Kemampuan Kerja secara simultan terhadap kinerja pegawai dan mengetahui faktor yang paling dominan terhadap kinerja pegawai di Kelurahan Baju Bodoa Kecamatan Maros Baru Kabupaten Maros. Peneltian ini menggunakan metode sampel dan metode pengumpulan data, data diperoleh dengan cara observasi, wawancara, kuesioner dan dokumentasi, sampel dalam penelitian ini berdasarkan pada metode Non Probability Sampling. Teknik Non Probability Sampling yang dipilih yaitu dengan Sampling Jenuh (sensus) yaitu metode penarikan sampel bila semua anggota populasi dijadikan sampel. Hasil dari pengujian menunjukkan bahwa secara simultan ketiga variabel berpengaruh signifikan terhadap Kinerja Pegawai sedangkan variabel yang paling dominan yaitu Faktor Kemampuan Kerja.
\end{abstract}

Kata Kunci: Lingkungan Kerja, Kompensasi, Kemampuan Kerja, Kinerja

\begin{abstract}
This research aims to determine the effect of working environment, compensation and ability to simultaneously work on employees ' performance and to know the most dominant factor in the performance of employees in the village of the new Maros District Bodoa District, Maros. This study uses sample methods and data collection methods, data obtained by observation, interviews, questionnaires and documentation, samples in this study are based on NonProbability Sampling methods. NonProbability Sampling technique is selected with saturated Sampling (census) i.e. the method of sample withdrawal when all population members are made samples. The results of the test show that simultaneously the three variables have significant effect on the employee's performance while the most dominant variable is the job capability factor.
\end{abstract}

Keyword: Working environmen, Compensation, Work and performance capabilities 


\section{PENDAHULUAN}

Sumber daya manusia memegang peranan penting sebagai pelaksana dan sekaligus penggerak roda pembangunan demi terlaksananya program-program pembangunan yang direncanakan. Selain itu sumber daya manusia merupakan potensi yang harus senantiasa dikembangkan karena bagaimanapun sumber daya alam yang ada tanpa pengelolaan yang baik dari sumber daya manusia maka tidak akan menghasilkan sesuatu. Tumpuan utama organisasi dalam menghadapi perubahan global adalah pada sumber daya manusia. Kemampuan organisasi untuk berkembang tidak lebih daripada kemampuan sumber daya manusianya untuk berkembang. Sumber daya manusialah yang menunaikan tugas-tugas organisasi dalam kerangka kerja yang terarah. SDM merupakan modal non material dan non financial dalam organisasi yang mutlak sifatnya karena ia merupakan aset utuama organisasi. Oleh karena itu, pengembangan SDM bukan lagi beban tetapi merupakan modal perkembangan organisasi.

Dalam era otonomi sekarang ini, organisasi/instansi pemerintah di daerah, khususnya yang berinteraksi langsung dengan masyarakat dituntut memiliki komitmen yang tinggi untuk menjalankan salah satu fungsinya yang sangat penting yaitu urusan atau fungsi pelayanan masyarakat. Fungsi pelayanan kepada masyarakat harus mendapat perhatian dari para pegawai kelurahan mengingat mereka adalah abdi masyarakat dan dituntut bisa memberikan pelayanan yang terbaik bagi masyarakat. Dengan demikian, setiap organisasi pemerintah diharapkan mampu mendayagunakan sumber saya manusia serta seluruh potensi yang ada dalam rangka pencapaian tujuan organisasi.

Menurut (Anwar \& Mangkunegara, 2005) pada umumnya kinerja dibedakan menjadi dua, yaitu kinerja individu dan kinerja organisasi. Kinerja individu adalah hasil kerja karyawan baik dari segi kualitas maupun kuantitas berdasarkan standar kerja yang telah ditentukan, sedangkan kinerja organisasi adalah gabungan dari kinerja individu dengan kinerja kelompok. Kinerja yang tinggi dapat diwujudkan, apabila dikelola dengan baik. Itulah sebabnya setiap organisasi perlu menerapkan manajemen kinerja. Berkaitan dengan manajemen kinerja ini, seringkali orang membuat kesalahan dengan mengira bahwa mengevaluasi kinerja adalah manajemen kinerja.

Padahal mengevaluasi kinerja atau memberikan penilaian atas kinerja hanyalah merupakan sebagian saja dari sistem manajemen kinerja. Sebab menurut (Rivai, Gani, \& Murfat, 2019) yang dimaksud dengan manajemen kinerja adalah sebuah proses komunikasi yang berkesinambungan/berlangsung terus-menerus, yang dilaksanakan berdasarkan kemitraan antara seorang karyawan dengan penyelia langsungnya. Proses ini meliputi kegiatan membangun harapan yang jelas serta pemahaman mengenai pekerjaan yang akan dilakukan. Dengan demikian manajemen kinerja merupakan sebuah sistem yang memiliki sejumlah bagian, yang keseluruhannya harus diikutsertakan, jika mengharapkan atau menghendaki system. Fenomena yang terjadi selama ini banyak instansi pemerintah yang belum mempunyai karyawan/pegawai dengan kompetensi yang memadai, ini dibuktikan dengan rendahnya produktivitas karyawan dan sulitnya mengukur kinerja karyawan di lingkup instansi pemerintahan. 
Terdapat beberapa faktor yang mempengaruhi kinerja pegawai pada Kelurahan Baju Bodoa Kecamatan Maros Baru Kabupaten Maros, yang secara garis besarnya adalah faktor kemampuan, faktor kompensasi dan faktor lingkungan kerja. Kurangnya kemampuan, pemberian kompensasi yang tidak sesuai dan lingkungan kerja yang tidak nyaman menyebabkan kinerja pegawai sampai saat ini masih belum optimal. Hal ini terlihat antara lain masih terdapatnya tugas-tugas yang belum memenuhi harapan, belum diterapkannya manajemen berdasarkan karier, adanya kecenderungan untuk menunda waktu penyelesaian pekerjaan dan kuantitas serta kualitas hasil pekerjaan yang kurang memenuhi harapan.

Menurut (Rahmajulita, 2016). linkungan kerja adalah segala sesuatu yang ada disekitar karyawan dan dapat mempengaruhi dalam menjalankan tugas yang diembankan kepadanya misalnya dengan adanya air conditioner (AC), penerangan yang memadai dan sebagainya. Lingkungan kerja adalah sesuatu yang ada di lingkungan para pekerja yang dapat mempegaruhi dirinya dalam menjalankan tugas seperti temperatur, kelembapan, ventilasi, penerangan, kegaduhan, kebersihan tempat kerja dan memadai tidaknya alat-alat perlengkapan kerja.

Menurut (Yugusna, Fathoni, \& Haryono, 2016) lingkungan kerja dapat diartikan sebagai keseluruhan alat perkakas yang dihadapi, lingkungan sekitarnya dimana seorang bekerja, metode kerjanya, sebagai pengaruh kerjanya baik sebagai perorangan maupun sebagai kelompok. Sedangkan menurut (Mardiana, 2005:78) lingkungan kerja adalah lingkungan dimana pegawai melakukan pekerjaannya sehari-hari. Dari beberapa defenisi diatas dapat disimpulkan bahwa lingkungan kerja adalah segala sesuatu yang ada disekitar para pekerja/karyawan yang dapat mempengaruhi kepuasan kerja karywan dalam melaksanakan pekerjaannya sehingga akan diperoleh hasil kerja yang maksimal, dimana dalam lingkungan kerja tersebut terdapat fasilitas kerja yang mendukung karyawan dalam penyelesaian tugas yang bebankan kepada karyawan guna meningkatkan kerja karyawan dalam suatu perusahaan. Manfaat lingkungan kerja adalah menciptakan gairah kerja, sehingga produktivitas kerja meningkat.

Sementara itu, manfaat yang diperoleh karena bekerja dengan orang-orang yang termotivasi adalah pekerjaan dapat diselesaikan dengan tepat. Artinya pekerjaan diselesaikan sesuai standar yang benar dan dalam skala waktu yang ditentukan. Kinerjanya akan dipantau oleh individu yang bersangkutan dan tidak akan membutuhkan terlalu banyak pengawasan serta semangat juangnya akan tinggi.

(Wijaya, 2019). Kompensasi merupakan faktor yang memengaruhi produktivitas kerja. Pendapat tersebut diperkuat oleh Rachmawati (2008: 143) mengatakan bahwa kompensasi diberikan dengan tujuan memberikan rangsangan kepada tenaga kerja untuk meningkatkan prestasi kerja, efisiensi dan efektivitas produktivitas kerja. Apabila kompensasi diterapkan dengan baik akan menciptakan motivasi. Menurut (Nasir, et.al, 2020) motivasi adalah kondisi yang menggerakkan pegawai agar mampu mencapai tujuan dari motifnya. (Jegho,, 2019) mengatakan bahwa seseorang bersedia melakukan suatu pekerjaan karena dirangsang oleh motivasi. Jadi motivasi adalah faktor penting sebagai penggerak produktivitas kerja karyawan yang salah satunya didapat dari penerapan kompensasi yang baik.

Sementara itu Kompensasi merupakan faktor yang memengaruhi produktivitas kerja. Pendapat tersebut diperkuat oleh (Ayu Sarina, 2015) mengatakan bahwa kompensasi diberikan dengan tujuan memberikan rangsangan kepada tenaga 
kerja untuk meningkatkan prestasi kerja, efisiensi dan efektivitas produktivitas kerja. Apabila kompensasi diterapkan dengan baik akan menciptakan motivasi. Menurut (Esa, \& Prawitasari, 2012) motivasi adalah kondisi yang menggerakkan pegawai agar mampu mencapai tujuan dari motifnya. Salusu (2000: 429) mengatakan bahwa seseorang bersedia melakukan suatu pekerjaan karena dirangsang oleh motivasi. Menurut (Fatmawati, Taufik \& Robustin, 2018) mengatakan bahwa "kompensasi dihitung berdasarkan evaluasi pekerjaan, perhitungan kompensasi berdasarkan evaluasi pekerjaan tersebut dimaksudkan untuk mendapatkan pemberian kompensasi yang mendekati kelayakan dan keadilan. Menurut (Ariyanto) yang dimaksud dengan kompensasi adalah segala sesuatu yang diterima karyawan sebagai balas jasa untuk kerja mereka."

Konsep kemampuan kerja adalah hasil dari kombinasi sumber daya manusia dalam hal tuntutan fisik, mental, sosial kerja, budaya, organisasi, dan lingkungan kerja (Fadli, M. F.) Konsep ini dapat dirumuskan sebagai "seberapa baik seorang pekerja dalam waktu dekat atau saat ini, dan bagaimana pekerja mampu melakukan pekerjaan yang diberikan sesuai dengan tuntutan pekerjaan, status kesehatan, kemampuan mental dan keadaan fisik pekerja (Wulandari, A., \& Hamzah, R). Penuaan Fungsional dapat diartikan sebagai penurunan kemampuan kerja, dan dapat menjadi penuaan yang kronologis atau berlanjut, tergantung pada tingkat kemampuan tubuh untuk memenuhi kemampuan kerja di saat mengalami penuaan. Kinerja adalah hasil seseorang secara keseluruhan selama periode tertentu didalam melaksanakan tugas, seperti standar hasil kerja, target atau sasaran kriteria yang telah ditentukan terlebih dahulu dan telah disepakati bersama (Abdulloh, A., \& Suwarna, A). Kinerja karyawan tidak hanya sekedar informasi untuk dapat dilakukannya promosi atau penetapan gaji bagi perusahaan.

Akan tetapi bagaimana perusahaan dapat memotivasi karyawan dan mengembangkan satu rencana untuk memperbaiki kemerosotan kinerja dapat dihindari. Kinerja karyawan perlu adanya penilaian dengan maksud untuk memberikan satu peluang yang baik kepada karyawan atas rencana karier mereka dilihat dari kekuatan dan kelemahan, sehingga perusahaan dapat menetapkan pemberian gaji, memberikan promosi, dan dapat melihat perilaku karyawan. Penilaian kinerja dikenal dengan istilah "performance rating" atau "performance appraisal". Menurut (Dewi, 2019), penilaian kinerja adalah proses penilaian ciri-ciri kepribadian, perilaku kerja, dan hasil kerja seseorang tenaga kerja atau karyawan (pekerja dan manajer), yang dianggap menunjang unjuk kerjanya, yang digunakan sebagai bahan pertimbangan untuk pengambilan keputusan tentang tindakantindakan terhadap bidang ketenagakerjaan. Suatu perusahaan melakukan penilaian kinerja didasarka pertimbangan bahwa perlu adanya suatu sistem evaluasi yang objektif terhadap organisasional. Selain itu, dengan adanya penilaian kinerja, manajer puncak dapat memperoleh dasar yang objektif untuk memberikan kompensasi sesuai dengan prestasi yang disumbangkan masing-masing pusat pertanggungjawaban kepada perusahaan secara keseluruhan. Semua ini diharapkan dapat membentuk motivasi dan rangsangan kepada msing-masing bagian untuk bekerja lebih efektif dan efisien.

Berdasarkan uraian yang telah dijelaskan, maka kerangka konseptual penelitian ini dapat digmbarkan sebagaimana tampilan pada Gambar 1. 
Gambar 1. Kerangka Konsep Penelitian

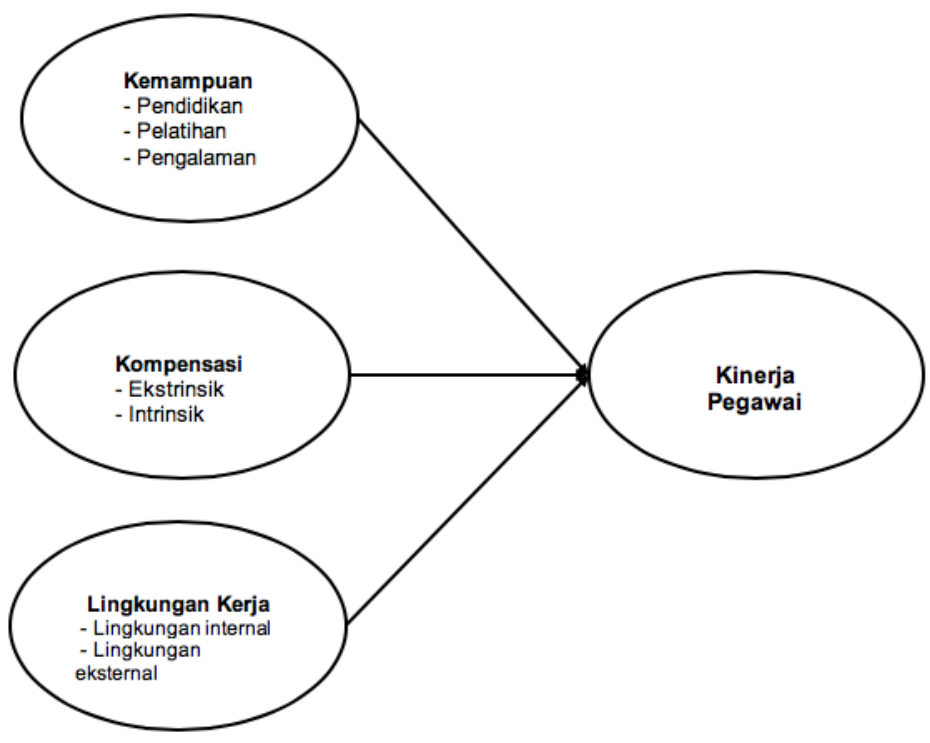

Hipotesis 1: Lingkungan kerja berpengaruh positif dan signifikan terhadap kinerja pegawai pada Kantor Kelurahan Baju Bodoa Kecamatan Maros Baru Kabupaten Maros.

Hipotesis 2: Kompensasi dan berpengaruh positif dan signifikan terhadap kinerja pegawai pada Kantor Kelurahan Baju Bodoa Kecamatan Maros Baru Kabupaten Maros.

Hipotesis 3: Kemampuan pegawai berpengaruh positif dan signifikan terhadap kinerja pegawai pada Kantor Kelurahan Baju Bodoa Kecamatan Maros Baru Kabupaten Maros.

Hipotesis 4: Faktor paling signifikan dan dominan berpengaruh terhadap kinerja pegawai pada Kantor Kelurahan Baju Bodoa Kecamatan Maros Baru Kabupaten Maros adalah kemampuan pegawai

\section{METODE PENELITIAN}

Penelitian ini dilakukan di Kantor Kelurahan Baju Bodoa Kecamatan Maros Baru Kabupaten Maros dengan jumlah sampel berjumlah 14 orang yang memiliki jabatan dan golongan yang berbeda. Setelah keseluruhan data terkumpul, selanjutnya dapat ditarik kesimpulan dari sejumlah data yang dikumpulkan sehingga memproleh hasil penelitian yang digunakan untuk menjawab masalah penelitian. Analisis dan juga bertujuan untuk menunjukkan hubungan antara fenomena yang terkait seputar penelitian. Scatter diagram (diagram tebar), yaitu pembuatan diagram sebaran dari kinerja hasil penilaian pelaksanaan setiap aparatur Kantor Kelurahan Baju Bodoa Kecamatan Maros Baru Kabupaten Maros yang menjadi responden penelitian. Metode ini dipakai untuk menguji, apakah distribusi kinerja dimaksud memiliki distribusi normal atau tidak. Diagram ini dibuat dengan mempergunakan perangkat lunak SPSS 22.00 for Windows. Pada diagram ini yang menjadi sumbe horizontal ailah segenap responden, sedang sumbu tegaknya ialah kinerja pegawai. Selanjutnya disusun 
disttribusi frekuensi. Mengukur seluruh variabel bebas dengan uji statistik yaitu uji Fisher (uji - F)

Dimana :

$$
Y=\beta_{0}+\beta_{1} X_{1}+\beta_{2} X_{2}+\beta_{3} X_{3}+e_{1}
$$

Y

$\beta_{0}$

$\beta_{1}-\beta_{3}$

$\mathrm{X}_{1}$

$X_{2}$

$\mathrm{X}_{3}$

$\mathrm{e}$
: Kinerja pegawai

: Konstanta

: Koefisien regresi yang akan dicapai

: Lingkungan Kerja

: Kompensasi

: Kemampuan

: Kesalahan estimasi

\section{HASIL PENELITIAN DAN PEMBAHASAN}

\section{Hasil}

Dari tabel dibawah ini adalah hasil pengujian data dengan menggunakan regresi linear berganda dengan bantuan program SPSS. Hasil output tersebut dapat terlihat dalam lampiran dan ringkasan hasilnya dapat dilihat pada tabel 1

\section{Ringkasan hasil analisis regresi linear berganda}

\begin{tabular}{lrrrr}
\multicolumn{1}{c}{ Variabel } & Koefisien & Standar error & T value & Prob \\
\hline Konstanta & .699 & 3.817 & .183 & .000 \\
\hline Lingkungan_Kerja & .258 & .175 & 1.478 & .005 \\
\hline Kompensasi & .184 & .109 & 1.690 & .026 \\
\hline Kemampuan_kerja & .266 & .223 & 1.189 & .022 \\
\hline \multicolumn{1}{c}{ Adjusted R square $=0.653$} & $\mathrm{~F}=13.154$ & $\mathrm{sig} \mathrm{F}=0.000$ & $\mathrm{R}=0.808$ \\
Sumber $:$ Hasil Olah Data SPSS & & & \multicolumn{2}{c}{}
\end{tabular}

Dengan demikian model persamaan regresi berganda yang diperoleh dari hasi pengujian adalah sebagai berikut:

$$
Y=0.699+0.258 X 1+0.184 X 2+0.266 X 3
$$

Dari tabel diatas diperoleh hasil-hasil sebagai berikut yang dapat dijelaskan untuk masing-masing variabel adalah sebagai berikut: 


\section{Model Summary(b)}

\begin{tabular}{|c|c|c|c|c|c|c|c|c|c|c|}
\hline \multirow[t]{2}{*}{ Model } & \multirow[t]{2}{*}{$\mathrm{R}$} & \multirow[t]{2}{*}{ R Square } & \multirow[t]{2}{*}{$\begin{array}{l}\text { Adjusted R } \\
\text { Square } \\
\end{array}$} & \multirow[t]{2}{*}{$\begin{array}{l}\text { Std. Error of the } \\
\text { Estimate }\end{array}$} & \multicolumn{5}{|c|}{ Change Statistics } & \multirow[t]{2}{*}{$\begin{array}{l}\text { Durbin- } \\
\text { Watson }\end{array}$} \\
\hline & & & & & $\begin{array}{l}\text { R Square } \\
\text { Change }\end{array}$ & F Change & df1 & df2 & $\begin{array}{c}\text { Sig. F } \\
\text { Change }\end{array}$ & \\
\hline 1 & ,808(a) & 653 & 603 & ,73043 & 903 & 451,900 & 2 & 97 & ,000 & 1,131 \\
\hline
\end{tabular}

1. Untuk variabel kinerja kostanta sebesar 0,699 dengan tanda positif yang berarti nilai diatas adalah nilai kinerja dan nilai tersebut akan tetap baik dipengaruhi atau tidak dipengaruhi variabel lingkungan kerja, kompensasi, dan kemampuan kerja.

2. Koefisien $\mathrm{R}$ sebesar 0,808 , ini menunjukkan bahwa hubungan antara variabel dependen dengan variabel independen adalah kuat. Definisi kuat karena angka tersebut diatas 0,05 .

3. Uji koefisien determinasi (Adjusted R Square) bertujuan untuk menunjukkan persentase tingkat kebenaran prediksi dari pengujian regresi yang dilakukan. Semakin besar R2, maka semakin besar variasi dari variabel yang dapat dijelaskan oleh variabel independen. Koefisien determinasi juga digunakan untuk mengetahui proporsi pengaruh variabel independen terhadap variabel dependen. Nilai R2 sebesar 0,653 atau $65,3 \%$ berarti variasi atau naik turunnya kinerja pegawai diperoleh pegawai dari lingkungan kerja, kompensasi dan kemampuan kerja. Sedangkan 34,7\% (sisanya (100-60,3)) dipengaruhi oleh variabel lain.

\section{Pembahasan}

\section{Pengaruh Lingkungan Kerja terhadap Kinerja}

Untuk nilai koefisien sebesar 0,258 dengan tanda positif yang berarti bahwa lingkungan kerja berpengaruh positif terhadap kinerja pegawai atau dapat diartikan pula setiap perbaikan yang di lakukan secara terus menerus akan meningkatkan kinerja pegawai. Hal ini sejalan dengan penelitian yang di lakukan oleh Indriyani (2000:80) menjelaskan bahwa dinamika kerja akan hidup dan survive apabila lingkungan kerja selalu mendapat perhatian dari pengambil kebijakan. Lingkungan kerja yang perlu diperhatikan adalah kondisi fisik dan tempat bekerja, suasana kerja yang mendukung untuk betah bekerja dan keharmonisan unsur-unsur yang terlibat dalam aktivitas kerja. Tentu pendapat ini mengisyaratkan bahwa untuk meningkatkan kinerja aparat, faktor lingkungan memberikan pengaruh. Ini dapat dilihat apabila kondisi fisik lingkungan kerja terpenuhi, misalnya ruangan kerja yang luas, memiliki dekorasi ruangan yang teratur, dilengkapi dengan alat dan perlengkapan yang lengkap, ditunjang dengan suasana lingkungan kerja yang tenang, bersih, indah dan nyaman akan memberikan respon bagi pegawai untuk bekerja lebih giat, apalagi rekan-rekan kerja memahami pentingnya keharmonisan kerja diciptakan dalam lingkungan kerja. Pemahaman lingkungan kerja secara eksplisit tidak dapat diabaikan dari faktor-faktor lain yang berpengaruh terhadap kinerja aparat. Mustahil seorang karyawan akan bekerja secara optimal dalam menjalankan aktivitas kerjanya apabila kondisi lingkungan kerjanya tidak terpenuhi, tidak lengkap dan tidak harmonis. 
Kondisi yang demikian akan memberikan adanya kesan yang kurang baik untuk bekerja, ketidakbetahan dan kemalasan bekerja

\section{Pengaruh Kompensasi Terhadap Kinerja}

Nilai koefisien sebesar 0,184 dengan tanda positif yang berarti dengan pemberian kompensasi berupa bonus ataupun penghragaan berpengaruh positif terhadap kinerja atau dapat diartikan pula setiap pemberian kompensasi akan meningkatkan kinerja pegawai itu sendiri. Hasil ini sejalan dengan teori yang di kemukakan oleh (Handoko, 2019) yang menjelaskan bahwa kommpensasi itu merupakan segala sesuatu yang diterima karyawan sebagai balas jasa atas kerja mereka. Pemberian kompensasi merupakan salah satu meningkatkan kerja mereka, motivasi dan kepuasan karyawan. Kompensasi tidak hanya berkaitan dengan imbalan-imbalan moneter saja, tetapi juga pada tujuan dan imbaan intrinsik organisasi seperti pengakuan maupun kesempatan promosi.

\section{Pengaruh Kemampuan Kerja terhadap Kinerja}

Koefisien sebesar 0,266 dengan tanda positif yang berarti kemampuan kerja dalam melaksanakan tugas berpengaruh pada peningkatan kualitas audit atau dapat diartikan bahwa setiap kenaikan nilai kemampuan kerja akan meningkatkan kinerja pegawai. Hasil penelitian ini sejalan dengan teori dalam ilmu psikologi yang menjelaskan bahwa, kemampuan (ability) pegawai terdiri dari kemampuan potensi (IQ) dan kemampuan reality (knowledge + skill) artinya, pegawai yang memiliki IQ di atas rata-rata denga pendidikan yang memadai untuk jabatannya dan terampil dalam mengerjakan pekerjaan sehari-hari, maka akan lebih mudah mencapai kinerja yang diharapkan. Oleh karena itu, pegawai perlu ditempatkan pada pekerjaan yang sesuai dengan keahliannya (the right man in the right place, the right man on the right job). Untuk meningkatkakan Kemampuan pegawai, ada beberapa alternative yang bisa mendukung untuk peningkatan kinerja yaitu melalui peningkatan kualitasn pendidikan, dimana pendidikan merupakan usaha atau kegiatan manusia yang dijalankan dengan teratur, dan berencana untuk menambah wawasan. Pendidikan merupakan wadah untuk meningkatkan kualitas pegawai. Dengan demikian melalui pendidikan kita akan mampu untuk mengambangkan kepribadian, sikap mental, kreativitas dan inovasi serta pengetahuan sumber daya manusia. Pendidikan di dalam suatu organisasi merupakan proses pengembangan kemampuan ke arah yang diinginkan oleh organisasi yang bersangkutan pendidikan bertujuan untuk membandingkan indiviidu secara formal di sekolah, akademi dan perguruan tinggi, yang berfungsi untuk meningkatkan keahlian teoritis, konseptual dan moral pegawai Alternatif lainnyan untuk meningkatkan kemauan pegawai lewat pelatihan untuk mengembangkan sumber daya manusia yaitu untuk mengembangkan aspek kemampuan intelektual dan kepribadian manusia. (Purwaningrum, Kusriyanto \& Supriyanto, 2013) mengemukakan bahwa suatu pelatihan dikatakan berhasil atau efektif apabila ciri-ciri rancangan pelatihan meliputi Memiliki sasaran yang jelas, dan hasilnya sebagai tolak ukur, Disajikan oleh tenaga pengajar yang cakap dalam menyampaikan atau menginformasikan ilmunya dan mampu memberikan motivasi para peserta. Dalam era informasi, keterampilan, kemampuan dan bahkan keahlian yang dimiliki oleh seseorang, cepat menjadi usang dan ketinggalan. Hal ini menunjukkan bahwa perubahan dan peningkatan kemampuan yang diperoleh 
melalui diklat memiliki waktu efektivitas yang relatif pendek. Untuk itu materi diklat setiap saat harus dapat dikembangkan terus secara dinamis dan responsif terhadap perkembangan yang ada sekarang ini..

\section{KESIMPULAN}

Hasil penelitian ini menemukan bahwa secara Hasil dari pengujian menunjukkan bahwa secara simultan ketiga variabel berpengaruh signifikan terhadap Kinerja Pegawai sedangkan variabel yang paling dominan yaitu Faktor Kemampuan Kerja. Hasil penelitian ini jga menyarankan kepada peneliti selanjutnya agar dapat menggunakan variabel lain dalam mengukur prestasi kerja pegawai agar wawasan tentang faktor-faktor yang dapat mempengaruhi kinerja pegawai dapat bertambah.

\section{DAFTAR PUSTAKA}

Abdulloh, A., \& Suwarna, A. (2020). Program Keselamatan Dan Kesehatan Kerja, Kompetensi Dan Komitmen Organisasi Terhadap Kinerja Karyawan Departemen Human Resources Operational Pada Pt. Gajah Tunggal Tbk. Jmb: Jurnal Manajemen Dan Bisnis, 9(1), 21-30.

Anwar, P. M., \& Mangkunegara, P. (2005). Evaluasi Kinerja. Bandung: Refika Aditama. Buku Panduan Negara, Undang-Undang, (3).

Ariyanto, D. Pengaruh Motivasi Dan Kemampuan Kerja Terhadap Produktivitas Kerja Karyawan Pada Perusahaan Meubel Pt. Edistra Gesit Sejahtera Abadi Boyolali.

Ayu Sarina, D. I. N. D. A. (2015). Pengaruh Kompensasi Finansial Terhadap Kinerja Karyawan Pada Unit Usaha Bus Rapid Transit (Brt) Transmusi Pt Sarana Pembangunan Palembang Jaya (Sp2j) Palembang (Doctoral Dissertation, Politeknik Negeri Sriwijaya).

Dewi, S. A. (2019). Pengaruh Penilaian Kinerja Dan Kemampuan Kerja Terhadap Kinerja Karyawan Pt. Mentari Indah Gemilang Kabupaten Serdang Bedagai Sumatera Utara.

Esa, K. W., \& Prawitasari, D. (2012). Pengaruh Motivasi, Kemampuan Dan Disiplin Terhadap Kinerja Karyawan Pada Pt. Samudera Indonesia Di Semarang. Jurnal Jurusan Manajemen Fakultas Ekonomi Dan Bisnis Universitas Dian Nuswantoro (-), 1-11.

Fadli, M. F. (2020). Pengaruh Motivasi, Kemampuan Dan Kesempatan Terhadap Kinerja Karyawan Pada Rumah Sakit Umum Daerah Nanga Pinoh Kabupaten Melawi. Jurnal Ekonomi Integra, 10(1), 041-062.

Fatmawati, L. D., Taufik, M., \& Robustin, T. P. (2018). Pengaruh Gaya Kepemimpinan Dan Kompensasi Terhadap Kinerja Pegawai Kontrak Pada Badan Kepegawaian Daerah Kabupaten Lumajang. Jobman: Journal Of Organization And Bussines Management, 1(1), 194-204.

Handoko, H. (2019). Perlindungan Anak Terhadap Tindak Pidana Penelantaran Dalam Keluarga Berdasarkan Undang-Undang Nomor 35 Tahun 2014 Tentang 
Perubahan Atas Undang-Undang Nomor 23 Tahun 2002 Tentang Perlindungan Anak. Gema Genggong: Jurnal Hukum, Keadilan \& Budaya, 1(1).

Jegho, K. I. (2019). Hubungan Antara Kompensasi Dengan Prestasi Kerja Pegawai Pada Kantor Badan Keuangan Daerah Kota Kupang Provinsi Nusa Tenggara Timur (Doctoral Dissertation, Unika Widya Mandira).

Murfat, M. Z., \& Basalamah, M. S. (2018). Faktor-Faktor Yang Mempengaruhi Kinerja Karyawan Pt. Lion Mentari Airliner Makassar. Karimah.

Nasir, M., Murfat, M. Z., Basalamah, J., \& Basalamah, A. (2020). An Analysis Of Work Discipline, Work Environment And Employment Satisfaction Towards Performance. Jurnal Manajemen Bisnis, 11(1), 65-75.

Purwaningrum, Y., Kusriyanto, M., \& Supriyanto, L. (2013). Joint Properties Of Friction Stir Welded 6063 T3 Aluminium Alloys With Variation Of Preheat Methode.A

Rahmajulita, S. (2016). Pengaruh Lingkungan Kerja Dan Kepuasan Kerja Terhadap Turnover Intention Perawat Di Rumah Sakit Amc Bandung (Doctoral Dissertation, Universitas Widyatama).

Rivai, R., Gani, M. U., \& Murfat, M. Z. (2019). Organizational Culture And Organizational Climate As A Determinant Of Motivation And Teacher Performance. Advances In Social Sciences Research Journal, 6(2), 555-566.

Wijaya, K. A. (2019). Pengaruh Pelatihan, Kompensasi, Disiplin Dan Lingkungan Kerja Pada Kinerja Karyawan (Doctoral Dissertation, Skripsi, Universitas Muhammadiyah Magelang).

Wulandari, A., \& Hamzah, R. (2019). Dampak Disiplin Kerja Dan Kemampuan Kerja Terhadap Prestasi Kerja Karyawan. Jurnal Signaling, 8(2), 41-47.

Yugusna, I., Fathoni, A., \& Haryono, A. T. (2016). Pengaruh Gaya Kepemimpinan Demokratis Dan Lingkungan Kerja Terhadap Kinerja Dan Kedisiplinan Karyawan (Studi Empiris Pada Perusahaan Spbu 44.501. 29 Randu Garut Semarang). Journal Of Management, 2(2). 